\title{
RETRATO DE LAS CALLES EN LA CIUDAD VACÍA
}

La tarde sobre el edificio es una sombra larga como un mantel sobre la mesa o la túnica de algún santo olvidado Extendidas por el horizonte las hojas y sus quinientas voces anuncian la llegada del otoño.

\section{EN EL FIN DEL MUNDO, EL SOL SE LEVANTA SOBRE LOS LÍMITES DE LA CIVILIZACIÓN}

En la guerra hay un baldío

En el baldío

Un perro

Y frente a él

Termina el horizonte.

\section{LOS PERROS NO DEJABAN DE LADRAR}

Los autos y sus luces

Pasan en la noche

Como insectos milagrosos

Nosotros regresamos al temor primigenio:

La oscuridad 